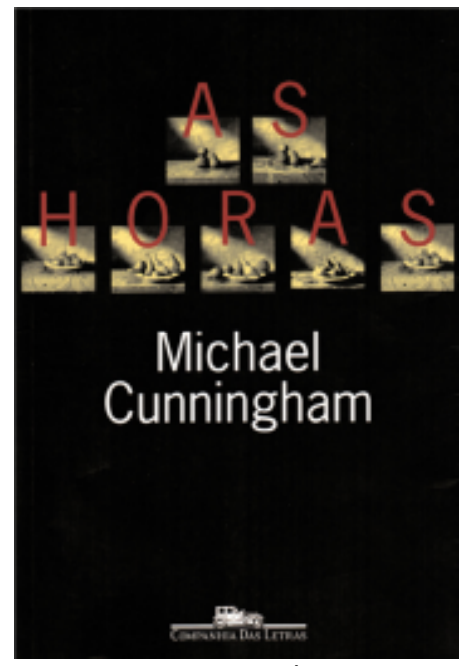

Capa do livro

\title{
Memória e rede no romance As horas
}

\section{Carlos Antônio Fernandes}

Aluno do Curso de Especialização em Ensino de Leitura e Produção de Texto em Língua Portuguesa, Faculdade de Letras/UFMG.

\section{CUNNINGHAM, Michael. As horas. Tradução Beth Vieira. São} Paulo: Companhia das Letras, 1999.

Nenhum escritor se faz sem o conhecimento da matéria, ou seja, das obras que o precederam e que são importantes para sua formação. O trabalho do escritor se desenvolve por meio de apropriações intertextuais. A literatura então é uma rede que se tece com palavras e idéias subsidiadas por palavras e idéias de outrem, na formação coletiva da cultura e dos pensamentos literários.

Um leitor mais experiente percebe "as vozes e os discursos" que sobressaem em determinada obra, suscitando-lhe 0 pensamento crítico. Podemos então afirmar que Michael Cunningahm, autor do romance As horas, foi um ávido leitor de Virgínia Woolf, a ponto de introduzir em seu romance uma Virgínia ficcional, embora o autor ateste em nota ao final do livro, que procurou reconstituir com a maior fidelidade possível os aspectos exteriores da vida, não só de Virgínia, como das pessoas de seu convívio que aparecem ao longo da história. 
Trata-se de uma narrativa intimista e introspectiva, em terceira pessoa, que usa o discurso indireto livre, e coloca o leitor em contato com as reflexões e lembranças dos personagens. Como exemplo disso, temos a seguinte passagem referente à personagem Clarissa: "Sente-se tão bem quanto naquele dia, em Wellfleet, aos dezoito anos, saindo pelas portas de vidro para um dia muito semelhante a este, limpo, tão claro que quase doía, exuberante, fecundo."

A narrativa decorre em três épocas: quando Virgínia Woolf escreve Mrs. Dalloway (1923), no momento em que Laura Brown lê a novela Mrs. Dalloway (1941) e quando a editora Clarissa Vaughn compra flores e organiza uma festa para seu melhor amigo, Richard (1999). Essas mulheres estão ligadas não só pela literatura, ao longo de toda a história, mas também por experiências, angústias, encontros e desencontros que marcaram suas vidas. Parafraseando Manuel Bandeira, esse é o romance da "vida inteira que poderia ter sido e que não foi". Nele, os personagens estão em constantes provações, desencadeadas por seus estilos e suas escolhas na vida. A atormentada Virgínia, vivendo em um subúrbio de Londres, tenta recompor sua vida com - marido Leonard. Entretanto, o que encontra é a insatisfação e o desespero. Laura Brown lê Mrs. Dalloway e se sente influenciada pela vida da personagem e pela escritora Virgínia Wollf. Quem é Laura Brown? Uma mulher casada, que tem um filho de três anos, e uma enorme insatisfação com a vida que leva. Por sua vez, Clarissa Vaughm vive na Nova Iorque do final dos anos 90 e, junto ao amigo Richard, experimenta um amor que parece a eterna paixão de um casal heterossexual, embora ambos sejam homossexuais. Na juventude, quando namorados, ele a chamava de Mrs. Dalloway.

Sobre os temas tratados no romance, afirma Liana de Camargos Leão, professora de literatura da Universidade Federal do Paraná: "em termos temáticos [...] Mrs. Dalloway e As horas são também muito próximos: Woolf e Cunninhgam exploram a identidade fluida que seus personagens experimentam, as sensações de amor à vida e de não pertencimento a esta que em diferentes momentos parecem emergir de seus corações."

A relação entre os personagens, vivendo em épocas distintas, é feita pela memória e pelos arquivos, sendo Virgínia o primeiro desses arquivos, já que sua personalidade e sua obra influenciaram as demais gerações contidas na narrativa. No romance de Cunnighgam, percebem-se tantos links entre literatura e memória que ele poderia ser analisado a partir das teorias de rede. Sendo assim, ler As horas é também, de certa forma, ler Mrs. Dalloway e a própria biografia de Virgínia Woolf - é entrar numa rede e transformar-se num hipertexto que vai sendo mudado no próprio momento da leitura. A variedade e a complexidade dos arquivos apresentados levam o leitor a uma experiência labiríntica de leitura da vida e da ficção. 